\title{
LES CRÒNIQUES BERLINESES D'EUGENI XAMMAR. L'ESCRIPTOR CATALÀ I LA CULTURA DE MASSES.
}

\author{
ÀLEX MATAS PONS
}

\begin{abstract}
Eugeni Xammar was the Berlin correspondent for newspapers La Veu de Catalunya and La Publicitat from 1922 to 1924 and for Ahora from 1930 to 1936. The Catalan journalist witnessed the events that determined the failure of the Weimar Republic and which, eventually, brought Hitler to power. This article analyzes Eugeni Xammar's intellectual condition from his discussion of these historical episodes and also from his follow-up on the increasingly decisive power of aesthetics and language of propaganda.
\end{abstract}

$S^{\mathrm{i}}$ Eugeni Xammar és conegut és, en bona part, gràcies als nombrosos retrats iteraris que van fer-ne amics i col·legues de professió, els quals van aconseguir que una generosa llegenda envoltés el personatge. També és conegut per les agres polèmiques que va protagonitzar, com les cartes publicades a La Veu de Catalunya contra la figura literària d'Eugeni d'Ors, escrites i signades amb el seu amic Josep Pla, o l'article publicat a la revista de l'exili Quadern d'Estudis en què atacava el paper que jugaven a la postguerra la revista Destino i els seus col·laboradors. És a dir, que Eugeni Xammar era un conversador afable i un home generós, capaç de guanyar-se l'estimació i el respecte dels amics, i era també un reconegut polemista, irat i intransigent, quan es tractava de defensar les seves conviccions catalanistes. Però és evident que aquestes dues qualitats no són prou perquè cap escriptor guanyi el reconeixement institucional i social.

De tota manera, ell tampoc hi tenia massa interès en aquest reconeixement, i no va fer cap esforç perquè el conjunt de les seves cròniques apareguessin recollides en forma de llibre. Persuadit com estava contra qualsevol mena de presumpció, no creia que hi hagués cap motiu perquè els seus articles transcendissin les circumstàncies contingents que explicaven, i pensava que el valor de la seva obra no era cap altre que la seva funció informativa i el seu respecte escrupolós pels fets. És pot dir que és autor d'un únic llibre, les memòries dictades al seu amic Josep Badia i Moret, publicades sota el títol de Seixanta anys d'anar pel món pocs mesos després de la seva mort. Es feia realitat així el pronòstic del seu amic Josep Pla: "En Xammar morirà inèdit”, havia escrit.

Les seves memòries són un testimoni excepcional del segle $\mathrm{XX}$, però ho són sobretot perquè són les memòries d'un periodista. No és només una qüestió d'estil 
— precís amb els fets i oportú amb les anècdotes - sinó què la seva memòria no destria allò que pertany estrictament a l'àmbit privat d'allò que pertany a l'àmbit públic. Llegim, per exemple, que les primeres lectures del nen Xammar van ser els diaris que arribaven a casa, El Noticiero Universal, El Español i El Siglo Futuro, i que el seu primer exercici escolar guardonat amb la màxima qualificació fou un "reportatge"; que el seu coneixement de llengües s'explica gràcies a la lectura de les cròniques de guerra del periodista francès Ludovic Naudeau a Le Journal, a les converses amb les sopranos italianes als camerinos del Liceu quan era crític musical al diari El poble català o a les lliçons de castellà que rebia dels redactors en cap de La Correspondencia de España quan corregien els seus articles; llegim que les seves amistats més duradores les havia de fer amb gent de l'ofici, com Carles Riba, Julio Camba o Josep Pla; que les seves conviccions i el seu activisme polític prenen forma quan llegeix el setmanari d'avantguarda Joventut amb els amics, quan escriu esporàdicament a La Tralla, o veu les destrosses que van fer els militars a les redaccions del diari La Veu de Catalunya i la revista Cu-cut!; llegim que durant la guerra civil a Espanya hi va haver un front diplomàtic i periodístic on s'escampaven rumors, com els que ell mateix va difondre als diaris Le Temps i L'Oeuvre, etc.

Així doncs, els seus records personals són també la memòria d'un segle de periodisme - si més no dels anys més complexos i convulsos del segle XX-i en dóna testimoni amb el seu estil acostumat. És un estil directe i descriptiu, com correspon a un autor que mai va comprometre la seva escriptura amb cap altre projecte editorial que no fos el de la premsa informativa. No hi ha, per tant, cap d'aquells "circumloquis propis dels alumnes aspirants a l'excel-lent de sintaxi" que ell creia tan poc adients per a la tasca del periodista. Però, com suggeríem abans, allò veritablement important és que en Xammar no cau mai en el parany de la banal impudícia ni fa seu l'antic culte romàntic per la biografia. Parla perquè és periodista, i aquesta és una opció que mereix una altra consideració que la seva simple reducció al gest "apassionat" o al gest "virtuós" de qui té predilecció per la discreció i la modèstia, perquè és una opció intel·lectual plenament conseqüent amb el seu exercici del periodisme. ${ }^{1}$

\section{XAMMAR I L'OFICI DE PERIODISTA}

Xammar sempre va interpretar que el seu ofici, a més d'un mitjà per a guanyar-se la vida, era també una eina al servei de la defensa dels drets dels individus. És evident que, individualista com era, sempre va entendre que el sistema que millor garantia l'exercici de la llibertat era la democràcia. És per això que les seves cròniques escrites des de Berlín gaudeixen d'un interès excepcional, perquè ell serà a la capital alemanya entre els anys 1922 i 1924, per primer cop, i entre els anys $1930 \mathrm{i}$ 
1936, el segon. És a dir, arriba com a corresponsal de La Veu de Catalunya quatre anys més tard que hagi estat aprovada la constitució de la República de Weimar i marxa definitivament un cop ha esclatat la Guerra Civil a Espanya i quan Hitler es prepara per a presidir la inauguració dels Jocs Olímpics a Berlín.

Quan arriba, Xammar participa de les moltes expectatives que genera a Europa l'aprovació de la constitució de 1919 i des de Berlín explicarà la complexitat política d'una constitució segellada amb els vots de partits polítics fortament antirepublicans i d'un govern que haurà de fer front a una llarga llista d'entrebancs: les condicions econòmiques derivades de la derrota a la Gran Guerra i les dures imposicions del Tractat de Versalles, el vertigen de la inflació i la invasió de les tropes franceses de la conca del Ruhr, el cop d'estat fallit a Munich i la manca d'autoritat política de Berlín envers les forces centrífugues dels Länder. Però, Xammar, quan arriba, també participa de les expectatives que genera la gran metròpoli cultural en què ha esdevingut Berlín, un cop l'any 1920 una reforma municipal va permetre finalment planificar la incorporació de l'extraradi al vell Berlín i va provocar que la ciutat sumés aleshores més de quatre milions d'habitants, i passés a ser la tercera ciutat del món en nombre d'habitants, després de Londres i Nova York.

Xammar arriba a una gran metròpoli on hi havia més premsa que enlloc; una ciutat literalment empaperada, segons llegim a les conegudes cròniques berlineses de Joseph Roth i Franz Hessel, o segons veiem a la pel-lícula de Walter Ruttmann Berlín: Simfonia d'una gran ciutat (1927), on el ritme urbà de la gran ciutat depèn de les imatges dels titulars de les primeres planes que es projecten a la pantalla i les dels venedors de diaris al carrer. Hi ha un munt de publicacions periòdiques i Eugeni Xammar envia tres cròniques consecutives l'abril del 1923 tot mirant de fer un resum sintètic d'aquest "panorama variat i pintoresc que la premsa de Berlín ofereix al llegidor". ${ }^{2}$ El seguiment que faran les seves cròniques de l'evolució d'aquesta gran indústria de la informació - que destaca tant per les seves enormes dimensions com per la influència que exerceix en tots els àmbits de la vida política $i$ cultural del país - serà també el seguiment de la salut democràtica de la República de Weimar.

Com correspon a les cròniques d'un corresponsal destinat a Berlín, els seus articles narren els fets polítics que fan difícil la consolidació d'una jove democràcia com la que s'estava assajant a Alemanya des de l'any 1919. La seva primera crònica, significativament, porta per títol "La República encara té por", i explica com la constitució neix dèbil des del mateix moment de la seva aprovació i com és incapaç de fer front als múltiples atacs de les diverses forces reaccionàries. ${ }^{3}$ Llegirem, per exemple, com és de còmic i absurd el sistema judicial heretat de l'imperi i comenta el "veredicte escandalós" del "procés Harden", un periodista republicà a qui van intentar matar poques setmanes després que hagués estat assassinat Walter Rathenau, el ministre d'Exteriors. També llegirem la feblesa amb què la República 
fa front les "dictadures locals", com la de Baviera, on el "rústic" Gustav von Kahr suprimeix lleis republicanes i habilita l'antic "sometent monàrquic i nacionalista encarregat de trencar la nou del coll als republicans, socialistes i jueus. Sobretot els jueus" (Xammar, L’ou 159). També llegirem, poc després de l'arribada de Hitler al poder l'any 1933 i l'endemà mateix de la crema del Reichstag, com s'executa, com és sabut, no només la prohibició del Partit Comunista, sinó que s’aprova un decret llei que posa fi a totes les llibertats individuals inscrites a la Constitució: inviolabilitat del domicili, dret de la propietat, secret de correspondència, etcètera.

En fi, Xammar dóna a conèixer quins són els grans esdeveniments històrics que ensorren un règim liberal $\mathrm{i}$ un sistema parlamentari. Però també explica què li succeeix al periodisme, i llegim que aquell panorama "variat i pintoresc" ha esdevingut poc a poc un panorama uniforme i avorrit: "La prensa alemana es hoy día menos divertida que nunca", diu el títol d'una crònica seva enviada el mes d'octubre de 1935 al diari Ahora. En Xammar comprova que aquella extraordinària indústria informativa s'ha anat aprimant poc a poc. Llegim que dels 44 periòdics amb dues edicions diàries de 1933, ja només en queden 33. I no és tracta en cap cas de brindar arguments a l'ingenu elitisme, perquè en Xammar ja avisa que no hi ha una millora de la qualitat en aquesta reducció de la quantitat, sinó la convicció cada dia majoritària entre els propietaris de periòdics que no té sentit mantenir una empresa d'aquestes característiques en un estat totalitari. Aquesta és la convicció, com a mínim, de la família d'Hugo Stinnes, propietària del periòdic Deutsche Allgemeine Zeitung, abocada a la decisió de tancar un diari que Xammar ja havia presentat l'any 1923 als lector de $\mathrm{La}$ Veu de Catalunya, no sense ironia, amb les següents paraules: "d'una fulla raquítica i ensopida, destinada en temps de l'imperi a recollir les impressions del Ministeri d'Afers Estrangers, Hugo Stinnes, ficat a periodista, n'ha fet en pocs mesos el diari més gran d'Alemanya" (Xammar, L’ou 130).

Aquest procés segons el qual una premsa amena i ben informada esdevé incompatible amb un règim autoritari és seguit amb deteniment per Xammar. Evidentment, explica que són les pròpies decisions de les autoritats del règim les que el propicien. Les prohibicions i la censura són creixents i Xammar informa amb detall d'atacs com el que protagonitza Goebbels l'any 1933 al capdavant del seu ministeri de Cultura Popular i Propaganda, quan dicta una nova llei de premsa que nega obertament el dret dels periodistes a opinar sobre cap assumpte polític, moral o econòmic. Això equival a fer dels periodistes els nous membres dels cossos del règim- com "l'exèrcit, la policia, les duanes, els ferrocarrils, els correus i els telègrafs" - i liquida el principi liberal de l'ofici, que és en definitiva el de la lliure opinió. Una llei dramàtica, sense cap mena de dubte, que Xammar acompanya de la seva acostumada ironia quan pregunta on i com són els uniformes que, els diuen, hauran de vestir (Crónicas 146). La mateixa ironia acompanya la informació sobre 
tots i cadascun dels cops legislatius del règim: quan s'aprova la llei d'esterilització a la que es sotmetrien prop de 400.000 alemanys "malalts" (inclogueren a les llistes d'afectats des d'idiotes a borratxos), Xammar sentencia que la vida a Alemanya és cada dia més difícil per a tots aquells que en el fons l'única cosa que volien és passar l'estona de la forma més agradable possible (Crónicas 165); quan informa que el règim fa obligatòria l'assistència a la Festa Nacional del Treball, sentencia que és normal que el govern no vulgui permetre que els obrers prenguin una cosa tan "seriosa" pel seu cantó més "frívol" marxant d'excursió (Crónicas 175); i quan informa sobre la llei que prohibeix fer acudits que tinguin per protagonistes els homes del govern, l'última forma de fer crítica política que encara era possible, a Xammar ja no li cal recórrer a la ironia i endega directament els darrers acudits sobre Goebbels i Goering que escolta al carrer (Crónicas 228).

No només són els cops legislatius i les decisions de les autoritats del règim els que fan impossible el periodisme. Malgrat Xammar empra la mateixa ironia quan descriu l'atac contra el periodisme que quan descriu l'atac contra la resta d'institucions finalment doblegades - els partits polítics, els sindicats obrers, els estats autonòmics, l'exèrcit-, uns i altres atacs no signifiquen exactament el mateix dins el conjunt de la seva obra. Si la bona premsa esdevé, com dèiem, incompatible amb qualsevol règim autoritari és perquè és la institució que s'encarrega, emparada precisament sota el paraigües de garanties que li proporcionen la resta d'institucions, de fer accessible la veritat. El sistema democràtic és un règim d'opinió perquè la seva pròpia composició admet que la veritat no és més què un efecte produit per les negociacions, els pactes i els acords establerts entre diversos grups i comunitats rivals i els seus respectius interessos en conflicte. Per tant, segons la convicció liberal d'en Xammar, si el periodista pot dur a terme eficaçment la tasca de fer accessible la veritat és perquè aquesta és necessàriament provisional i circumstancial, i és sempre fruit de l'interès.

Només cal veure el generós retrat que fa a les pàgines de La Publicitat del canceller Marx i del seu partit, el Centre Catòlic: "Els membres del partit treballen per la glòria del cel a l'altre vida i això fa que els caps del partit, per la seva banda, no estiguin obligats, com els comunistes, els nacionalistes, i els monàrquics, a prometre a l'elector la felicitat completa per al mes que ve" (L'ou 214-215). Això era l'any 1924 quan fins i tot un escèptic com Xammar encara tenia prou esperances en la República de Weimar i confiava encara en el marge de maniobra dels polítics. Per contra, com a corresponsal del diari Ahora, l'any 1933, Xammar resumeix el programa del nou canceller alemany, Hitler, de forma ben diferent: "su programa es un programa clásico de dictador. Con breves y sencillas palabras promete la felicidad general" (Crónicas 103).

Si el règim democràtic és un règim d'opinió és perquè la veritat és accessible. El règim autoritari, en canvi, parlarà més que mai de la Veritat per a fer-la del 
tot inaccessible. Des de la perspectiva del periodista liberal, la fa inaccessible en més d'un sentit: inaccessible, perquè és més opaca que mai, ara que els interessos en conflicte ja no són els dels eliminats partits polítics sinó els de les partides del règim: el règim d'opinió esdevé així ara un impracticable règim de rumors; inaccessible també perquè la Veritat es concep sota els termes absoluts d'un inassolible idealisme. Això és el que expliquen les cròniques de Xammar, que cada cop més es fixen en la posada en escena dels espectacles governamentals i en el llenguatge que empren els seus líders; i si a les autoritats feixistes els hi passa per alt la ironia que, un cop cremat el Reichstag, la nova seu del parlament sigui el teatre de l'òpera de Kroll, a Xammar no. Ell descriurà com les sessions parlamentàries ara són "juntes generals de casino militar" on tothom - diputats, convidats, diplomàtics i premsa - aplaudeix de forma idèntica el Govern, i comprova com aquesta farsa és una reproducció fidel de la farsa que el Partit Nacionalsocialista interpreta als seus congressos: "un acte solemne d'aprovació de totes les paraules i tots els actes d'aquells que parlen i actuen en nom del Führer".

És per això que no diuen cap mentida les autoritats del règim quan presumeixen, tot just sortir de la primera sessió al nou parlament "teatral", d'haver aprovat més lleis en mitja hora de les que hauria aprovat el vell Reichstag en mig any, perquè la realitat és que han posat fi a tots els debats, les negociacions i les votacions que els feien nosa. Però, segons el parer de Xammar, aquests exasperants tràmits que les autoritats del règim han eliminat perquè, segons diuen, són elements paralitzants d'un sistema decadent on "els homes es discuteixen, les professions es barallen y les classes lluiten entre elles", són en realitat els millors indicadors d'un sistema que funciona: precisament perquè hi manca la solemnitat uniformada. És segons aquesta convicció que s'entén perquè Xammar trobava molt recomanable la candidatura de Stresemann per a presidir la República l'any 1925, perquè fins aleshores era a ell a qui el Parlament alemany li devia "el poc que té de parlamentari (la gresca, la improvisació i l'inesperat)" (L'ou 257).

\section{XAMMAR: UN INTEL·LECTUAL CATALÀ}

La ironia de Xammar és menys una qüestió d'estil que de filosofia política, i l'enginy no és un recurs per a satisfer la seva vanitat tot enlluernant els lectors, sinó una forma de compromís amb el llenguatge corrent. Aquest compromís defineix aquells periodistes que volen fer accessible la veritat, convençuts com ho estan de que la veritat, com dèiem, és sempre una veritat provisional i circumstancial perquè és fruit de l'interès. És un compromís eminentment intel-lectual i es fa més necessari que mai quan l'espai públic és ocupat per les formes sublims de la retòrica grandiloqüent que prometen una inaccessible Veritat absoluta. Malgrat 
tot, aquest compromís ha fet de Xammar, paradoxalment, un estrany en el context de la història intel-lectual europea, i en el sistema literari català, en particular. El fa un estrany perquè la figuració ideal, o la més habitual, de l'intel-lectual europeu és la d'un personatge carismàtic que empra sovint la retòrica grandiloqüent; una figura influent que té accés als mitjans de comunicació i que té prou autoritat cultural perquè les seves opinions sobre assumptes generals obtinguin àmplies repercussions. Xammar, en canvi, és un periodista que exerceix el seu ofici i, sota la influència del periodisme anglès, argumenta d'una manera senzilla, clara i fonamentada sobre dades de l'experiència. D'aquesta manera romandrà aliè a la polèmica que envolta els intel·lectuals des de la seva primera aparició històrica. Sempre hi ha hagut dubtes sobre quin és l'origen d'aquesta autoritat cultural que suposadament els legitima per a adreçar-se a un públic que va més enllà de la comunitat professional de la que són membres. Donat que l'intel·lectual és aquell que pot parlar sense cap restricció sobre tota mena de qüestions, és veritat que la seva competència és ben singular.

De fet, s'ha establert que la vocació de l'intel-lectual és la d'esdevenir una mena de sacerdot de l'opinió pública i el seu destí seria el d'afirmar allò que ningú gosa contradir o negar. És una figura que neix amb l'optimisme il·lustrat, però això vol dir que, tan bon punt la civilització s'ha constituït en norma política, neix també algú que s'encarregarà de recordar que la civilització no es la veritable civilització. Sigui quina sigui la fita política conquerida, fins i tot si acaba en la forma òptima del sistema representatiu i democràtic, sempre hi haurà qui tindrà la vocació de funcionari de la humanitat i dirà representar, des d'una posició independent, els interessos de tots. Això significa que l'intel-lectual no només aixeca suspicàcies perquè no està clar què el fa un emissor competent, mereixedor de ser el portaveu de l'opinió pública, sinó que també aixeca suspicàcies perquè tampoc estan gaire clars quins són els seus interessos.

És una figura inherentment ambigua, perquè malgrat no ser equivalent als savis o artistes que oferien els seus serveis a mecenes i monarques, tampoc gaudeix de la independència de la que presumeix i que suposadament el legitima. És veritat que neix quan el sistema burgés ha desenvolupat un espai prou autònom -és el que Pierre Bourdieu qualifica com a "mercat de béns simbòlics"- però això significa que tant els artistes com els intel-lectuals gaudeixen ara d'una posició indefinida que els permet establir estratègiques relacions d'interès amb els diferents grups que constitueixen el poder. No significa, en canvi, que gaudeixin d'independència absoluta. Segons la coneguda metàfora econòmica de Pierre Bourdieu, és precisament el seu "capital cultural" el que els permet ocupar una posició estratègica, però també inevitablement ambigua.

Però a Xammar no li cal legitimar la seva competència per a fer el paper de sacerdot de l'opinió pública: és periodista. Tampoc li cal presentar-se com a algú 
que parla des de la independència absoluta, perquè està al servei dels diaris que el contracten i els seus lectors. La seva escriptura sempre ha estat lligada a la realitat econòmica del seu temps i a la demanda d'un públic lector ampli i variat: va escriure, sota el pseudònim "Douglas Flint", una crònica social a La Publicidad titulada "En el Hipódromo", adreçada a les famílies benestants barcelonines; va escriure de forma anònima comentaris analítics i informatius al diari aliadòfil Iberia; va escriure cròniques de guerra durant la Primera Guerra Mundial a les pàgines de La Publicidad; va editar, com a redactor en cap de la revista Iberia, els cal-ligrames de Josep M. Junoy; va encarregar-se de la crítica musical del diari El poble català; etcètera.

A més de la varietat de registres amb els que estava familiaritzat gràcies al seu ofici, Xammar també va fer altres feines que compaginava amb el periodisme: traductor de novel-les franceses, dels rètols de les pel·lícules o els fulletons del servei turístic alemany, secretari dels Serveis d'Informació de les ambaixades espanyoles; empleat a la Societat de Nacions, etcètera. En definitiva, una dedicació professional que fa improbable l'habitual estil sublim, a vegades oracular o apocalíptic, en què cauen els intel-lectuals un cop esdevenen funcionaris de la humanitat, quan des del púlpit de la seva competència cultural i independència desinteressada empren una retòrica incendiària. L'experiència vital d'en Xammar i també el seu credo liberal contradiuen la presumpció d'insubornabilitat dels intel·lectuals i fan que els interpreti segons els compromisos que necessàriament establiran amb els altres i els interessos que hauran de compartir-hi. El seu compromís intel-lectual amb el periodisme, per tant, no li permet caure en la temptació de proposar-se com a portaveu autoritzat de ningú — malgrat sigui polèmicament autoritzat - ni usurpar la veu de cap ciutadà. Un compromís que queda clar quan l'any 1935, després d'escoltar un discurs que Hitler pronuncia davant de 20.000 persones, Xammar escriu a les pàgines del diari Ahora:

Ustedes me dirán que ésos no son modos de hablar, que un pueblo puede cambiar de idea y que no hay ninguna ley natural que impida a un pueblo en marcha detenerse o virar hacia la izquierda o hacia la derecha o desandar lo andado sencillamente. Es posible que tengan ustedes razón. Eso importa poco. Mi misión no es la de contarle a Hitler lo que dicen ustedes, sino la de contar a ustedes lo que dice Hitler (Crónicas 313).

Xammar està intel-lectualment compromès amb el seu ofici i això permet entendre encara millor perquè dèiem abans que en les seves memòries amb prou feines es pot diferenciar què pertany a l'àmbit privat $i$ què a l'àmbit públic, $i$ quan dèiem també que això no era només degut a una qüestió de passió professional o de modèstia personal. Ara entenem que Xammar escriu, fins i tot les seves memòries, des de la convicció que la seva veu mereix audiència només perquè exerceix o ha exercit correctament el seu ofici. No és només una qüestió de moralitat privada, 
perquè el compromís del periodista amb la veritat té una evident projecció pública i unes òbvies implicacions polítiques que fan factible que el periodista pugui ésser identificat segons els deures què Victor Klemperer entenia propis de l'intel-lectual: "sempre ha de conservar la llibertat de pensament i provar de transmetre-la al seu voltant" (139). Klemperer escriu això l'any 1946, tot just quan el règim feixista a Europa ha estat derrotat. Publica aquestes reflexions quan la reconstrucció europea fa més necessari que mai el lideratge dels intel-lectuals. Sobretot, perquè el règim nacionalsocialista els havia difamat sistemàticament. Segons Klemperer, rehabilitar la intel-ligència de les nacions no només és fer una raonable cessió del protagonisme social als agents més instruïts, sinó definir també d'una vegada per totes quines haurien de ser les qualitats i les responsabilitats d'aquests agents.

És per aquest motiu què cal llegir aquest breu article juntament amb un altre projecte seu que és encara molt més ambiciós: LTI. La lengua del Tercer Reich. Klemperer, a partir de les notes filologiques contingudes als diaris que va escriure durant els anys de feixisme, estudia quin és l'ús del llenguatge que fan les autoritats nazis i quin ha estat el seu poder narcotitzant o quins eren els efectes d'embriaguesa en aquells que escoltaven. El treball de Victor Klemperer no només és ara ja un treball de referència conegut per les veritats científiques que aboca, sinó que és també un exemple de com la definició de l'intel-lectual assajada en aquell breu text de 1946 ve acompanyada de manera exemplar pel compromís professional. El compromís professional d'un filòleg equival al compromís professional del periodista. Més enllà de si es fa des de l'acadèmia, escrivint i ensenyant, o es fa des de la redacció dels periòdics, informant i valorant, són dues versions idèntiques d'un mateix compromís amb el llenguatge. Un compromís que concep el llenguatge com un instrument del pensament gràcies al qual es pot persuadir amb arguments els interlocutors. L'intel-lectual fa, per tant, un ús exemplar del llenguatge i també analitza i estudia el llenguatge quan aquest persegueix altres finalitats que no siguin la de posar-se al servei dels objectius legítims dels països civilitzats.

En Xammar, evidentment, també va denunciar obertament el règim feixista $\mathrm{i}$ alguna vegada també va emprar un prosa oracular que pronosticava el malaguanyat desenllaç europeu: " $\mathrm{Si}$, como suele decirse, un milagro no lo impide, un gran país va a orientarse por el camino de la reacción, que puede ser el camino de la restauración o el camino de la revolución" (Crónicas, 98). Però allò realment interessant no és que fos capaç de predir esdeveniments desastrosos que després els historiadors han documentat des d'una distància que ell no va tenir, sinó allò que indica aquell "com sol dir-se" de la citació, és a dir, la seva reserva o distància respecte a un llenguatge pròpiament religiós que havia esdevingut, malauradament, hegemònic. Dit d'una altra manera: no interessa tant buscar en les seves denúncies i presagis la confirmació de l'estereotipada imatge de l'intel·lectual com llegir el 
seguiment sistemàtic que fa del llenguatge polític i de la "teatrecràcia" del Tercer Reich, segons la va batejar l'historiador Jacob Burkhardt.

Una de les primeres cròniques enviades a La Veu de Catalunya l'any 1922 subratlla l'òbvia mala intenció que hi ha darrere l'eufemisme "enllestits": "Segons la terminologia del criminal nacionalista alemany, Erzberger, Eisner, Haase, Rathenau, no són homes assassinats. Són, senzillament, homes "enllestits" (L’ou 46); després, cridarà l'atenció sobre la caducitat a Alemanya del significat tradicional dels mots i la inadequació entre la realitat política i la que les paraules designen: "Avui [els socialdemòcrates] són l'única força conservadora que hi ha a Alemanya. No s'ho diuen, naturalment. Però ho són. En canvi, els monàrquics, els quals continuen dient-s'ho per vici, no en tenen res. Són al contrari, la força més temeràriament revolucionària que hi ha a Europa" (L'ou 166); després cridarà l'atenció sobre els recursos declamatoris dels fabricants de tòpics, com el definitiu eclipsi del sentit dels substantius sota la preeminència dels adjectius, sempre hipòcrites, que l'acompanyen: "Dotze cossos de l'exèrcit i trenta sis divisions, al servei de la pau d'Europa", explica que diu el diari Lokal Anzeiger, quan tot just tothom parla de que cal trobar la pau "veritable", i no la pau "sense honor", la pau "sense llibertat", la pau "sense seguretat" de la que gaudien suposadament els alemanys. El problema, com diu Xammar, "resideix en els atributs" (Crónicas 256-259); després parlarà del llenguatge solemne del règim, que revesteix d'excepcionalitat qualsevol esdeveniment mancat de transcendència real: "este lenguaje elevado, sublime, resulta impresionante y casi incomprensible. Aquí es el lenguaje corriente" (Crónicas 297); etcètera.

\section{XAMMAR I EL PODER DE L'ESTÈTICA}

Xammar reconeix l'absoluta uniformitat i homogeneïtat del llenguatge del nacionalsocialisme, que amb els anys va ser l'únic llenguatge de domini públic. Tot el que es publicava a Alemanya mitjançant llibres, periòdics, formularis i escrits oficials havia de respectar escrupolosament les normes del Partit. No era un llenguatge absolutament nou, sinó que era un discurs pastoral fet d'un munt de paraules clau, la majoria manllevades del llenguatge religiós. ${ }^{4}$ Però no era només una qüestió de llenguatge, sinó una litúrgia més complexa on la salmòdia de les paraules claus del llenguatge nacionalsocialista venia acompanyada de posades en escena cada cop més espectaculars. Conforme el Partit Nacionalsocialista es va fent amb el poder, la normalitat democràtica i els seus ordinaris i vulgars escenaris seran substituïts per la cerimònia religiosa, generalment presidida pel líder màxim, Hitler, de qui s'esperen tota mena de miracles. La ideologia nacionalsocialista no és més que un conglomerat eclèctic de missatges redemptors que prometen seguretat, 
pau i felicitat en temps de crisi, i Xammar veu com la majoria de la ciutadania alemanya consumeix cada cop més convençuda una oferta política que no és més que litúrgia. És per això que descriu la teatralitat als carrers, la proliferació de reunions o festivals i l'ocupació de l'espai públic per tota mena d'icones visuals, uniformes i estrambòtiques dramatúrgies: “¿Pero quién es capaz de leer en el corazón de un obrero alemán que saluda a la romana?” (Crónicas 55), es pregunta l'any 1933, després d'haver resumit els continguts d'un discurs de Hitler als lectors del diari Ahora de Madrid.

Xammar veu com trontolla el sistema democràtic i liberal que ell defensa per culpa d'una tècnica que té poc a veure amb la lògica política i molt amb la manipulació psicològica. Ell veu la naturalesa estètica de l'aparició en política dels personatges que dirigiran el país i els descriurà, des de la seva còmica primera aparició fins a la seva grotesca consagració. La presentació que fa de Hitler l'any 1923, quan publica a les pàgines de La Veu de Catalunya "Baviera: una galeria de retrats", ja és la sarcàstica presentació d'algú absolutament insensible a la seva pròpia comicitat satírica: "Té el cap enlairat, la boca badada i els ulls a tres quarts de quinze i, prenent-ho tot plegat, un posat de satisfet, característic de les personalitats dictatorials, que n'hi ha per llogar-hi cadires" (L'ou 163). Amb prou feines havia passat un mes i Xammar té l'oportunitat d'entrevistar amb el seu amic Josep Pla aquest "personatge" que havia presentat als lectors catalans a partir només d'un simple retrat, i les seves paraules seran la confirmació de tot allò que ja havia dit sobre un home francament risible: "Entre la fotografia i l'home, equivalència absoluta. Es veu de seguida que Hitler és un d'aquests homes vinguts al món expressament per a fer-se retratar" (L'ou 198). En un context civilitzat, les ínfules i la pompa de personatges com Hitler irrompen com irromprien a l'escenari d'una opereta els personatges secundaris, i així ho dóna a entendre Xammar quan escriu la crònica sobre el cop d'estat protagonitzat per Hitler: "El cop d'estat com espectacle".

Aquesta detecció de com tot un moviment polític pot resumir-se en uns clixés lingüístics i un registre escenogràfic vol dir que Xammar no va menystenir mai la seva importància i el seu perill. Veiem un exemple quan torna sobre l'ús de l'eufemisme que ja havia detectat durant l'esmentat "procés Harden" el desembre de l'any 1922. Hi torna l'any 1924, quan segueix per als lectors de La Publicitat el judici contra els acusats d'intentar assassinar el general Von Seeckt:

S'acaba de celebrar a Berlín la vista d'una causa contra dos senyors molt patriotes i molt «racials», anomenats Thormann i Grandel, als quals s'acusava d'haver-se proposat l'«eliminació» del general Von Seeckt, cap de l'exèrcit alemany, i d'haver fet passos molt decidits per dur-la a terme. Dir eliminació vol dir assassinat. D'assassinar, els «racials» alemanys en diuen eliminar. [...] 
El tribunal diu que els preparatius dels senyors Thormann i Grandel per tal d'eliminar el general Von Seeckt s'havien limitat a comprar calces de muntar a terceres persones que mai havien tingut la intenció d'eliminar el general Von Seeckt. Sembla que això, segons el Codi alemany, no és delicte. En apreciar el veredicte, la premsa s'ha dividit. Els diaris de l'esquerra —el general Von Seeckt és un home de dreta, però no és «racial»— han dit que els jutges del Tribunal eren uns barrilaires disfressats. Els diaris racials han dit que el veredicte era un preciós veredicte. (L'ou 244-246)

En Xammar ho diu molt clar: "Tot plegat risible, però els senyors Thormann i Grandel portaven males intencions". El mateix es podria dir de Hitler i els seus còmplices, que havien protagonitzat pocs mesos abans aquell espectacle còmic del cop d'estat. L'eufemisme "eliminar" no ha desaparegut durant els dos anys que separen les dues cròniques esmentades, sinó que s'ha anat repetint mecànicament fins al punt d'haver-se naturalitzat malgrat la seva evident comicitat. L'assassinat ha acabat esdevenint una mena d'ofici a Alemanya, gràcies a la complicitat retòrica dels mitjans de comunicació i la impunitat dels membres d'aquest estrany gremi judicial. La República de Weimar que coneix Xammar ofereix ja nombrosos indicis de quins serien els mecanismes de tecnificació i organització que després empraria la pretensió totalitària del nacionalsocialisme. Goebbels, l'encarregat del Ministeri de Propaganda i Cultura Popular, és la figura que millor ho resumeix i serà omnipresent a les cròniques que Xammar escriurà a partir de l'any 1930 al diari Ahora. Ell unificarà tota la xarxa institucional i, un cop "purgats" els funcionaris que treballen a totes les institucions culturals - teatres, cinemes, ràdios, periòdics, conservatoris, museus i orquestres-, la uniformitat lingüística i teatral serà absoluta. Però la República de Weimar ja s'havia caracteritzat per l'ascens d'un grup social, els dels empleats, que gaudia del rang de funcionari, malgrat no rebre les seves mateixes proteccions, i que ja no compartia ni l'imaginari de la classe obrera ni les seves formes d'organització sindical. L'aparició i l'extensió demogràfica d'aquest grup de treballadors - contractats que es dedicaven fonamentalment a les funcions de venta i representació- havia significat aleshores una progressiva racionalització en l'economia i en la vida quotidiana en general. De la mateixa manera, l'oci i l'entreteniment d'aquests "funcionaris privats" es caracteritzava pel consum d'objectes i espectacle on el culte a la bellesa del cos físic s'expressava en la forma regular de la repetició i l'exactitud geomètrica, com poc després acostumaria a representar-se en les desfilades i cerimònies del Partit nazi.

Qui va analitzar millor aquesta realitat va ser Siegfried Kracauer. Ell va descriure, sobretot des de les pàgines del periòdic Frankfurter Zeitung, com era la vida social a Alemanya durant els mateixos anys que en Xammar hi vivia. Ell mateix explicava que la seva anàlisi la feia sobre "manifestacions superficials $\mathrm{i}$ insignificants" de la vida social, perquè les trobava més determinants que no "els 
judicis de l'època sobre ella mateixa". ${ }^{5}$ Es va capbussar en tota mena de productes i espectacles de la cultura de masses —el ball de les Tiller girls, les il-lustracions de les revistes de moda, els anuncis publicitaris, etcètera- i va constatar que el llenguatge distingit i sublim ocultava una sordidesa real, i que les brillants icones de joventut i fortalesa amagaven la realitat més ordinària. De manera idèntica, pocs anys després, els espectacles nazis buscarien reconciliar la lletjor de la nova tecnologia i les formes més familiars de la bellesa clàssica. Kracauer està atent a fets i expressions aparentment trivials que generalment passarien desapercebuts i els analitza sense cap pretensió conceptual totalitzadora, sense elaborar teories de caràcter general i sense establir regularitats concloents. Això és el que fa d'aquest escriptor de reportatges periodístics, que estan entre la crònica i el tractat etnogràfic, un intel-lectual insòlit en el camp científic de la teoria social.

L'atenció intelllectual a les formes de vida més ordinàries de Kracauer és comparable a l'atenció intel-lectual de Xammar a les formes de la política més ordinàries, i el difícil encaix de Kracauer en el sistema científic de la teoria social és comparable al difícil encaix de Xammar en el sistema literari en català. Quan el periodista català exerceix el seu ofici, no creu oportú dedicar-se només a informar els seus lectors sobre quin és el joc que s'ha establert entre les institucions i entre les persones involucrades en assumptes públics. Aquest joc és la política convencional i implica una quotidianitat marcada pel debat entre els partits polítics, entre els parlaments i entre la resta d'institucions d'una societat plural. Fins i tot si Xammar creu que aquesta avorrida quotidianitat és un indici de salut civil, prefereix fixar la seva atenció en fenòmens superficials que en realitat fan irrellevant el joc convencional de la política. Per exemple, Xammar escriu l'any 1935 al diari Ahora:

A cada nuevo acto solemne del partido gobernante queda trazado con más firmeza el perfil religioso del movimiento nacionalsocialista. Algunos jefes aseguran todavía en discursos poco meditados que el nacionalsocialismo no es una religión. Se equivocan. El día en que los alemanes, en lugar de saludarse en nombre de Dios empezaron a saludarse en nombre de Hitler, nació en Alemania un nuevo culto. (Crónicas 305)

La manifestació ordinària de la salutació, repetida mecànicament desenes de vegades al llarg d'un sol dia, assenyala que la política ha esdevingut culte religiós, que el debat ha estat substituit per la litúrgia de la veneració, que l'argumentació és ara simple sermó pastoral. O, per exemple, també informa múltiples vegades sobre quina era l'aparença i la imatge que oferia l'òpera Kroll, on tenien lloc els plenaris ficticis del règim un cop cremat el Reichstag: "El Reichstag alemán ha vuelto a presentar hoy el aspecto de las grandes solemnidades, que es, en régimen nacionalsocialista, su aspecto normal" (Crónicas 317-318).

No és cap casualitat que el mateix any 1946 que Victor Klemperer publicava 
el seu breu assaig El paper de l'intel-lectual en la societat, George Orwell escrivís l'influent "Politics and the English Language". És un text que ha estat àmpliament comentat i antologat, gràcies, entre altres coses, a les lloances que en va fer Lionel Trilling l'any 1955, quan era un dels representants més destacat de la intel-lectualitat novaiorquesa que tractava d'allunyar-se de les directrius soviètiques organitzada al voltant de la Partisan Review. Allò que van veure a Alemanya durant la República de Weimar i el règim feixista intel·lectuals com Xammar — des del periodisme-, Klemperer — des de la filologia— i Kracauer — des de la sociologia— George Orwell ho veurà com quelcom d'inherent a tots els sistemes polítics i totes les ideologies: "Political language — and with variations this is true of all political parties, from Conservative to Anarchist - is designed to make lies sound truthful and murder respectable, and to give an appearance of solidity to pure wind" (137).

Com hem vist que feien Xammar, Klemperer i Kracauer, ell també analitza exemples concrets trets de diversos mitjans de comunicació: denuncia, de fet, l'omnipresència del clixé, de l'eufemisme, de la grandiloqüència i de tot un munt d'estratègies retòriques i lingüístiques que bàsicament buscarien ofuscar la veritat. Aquest article ha estat prou popular com per a convertir Orwell en un reputat intel-lectual per al pensament democràtic i liberal, però, paradoxalment, la seva denúncia de l'ofuscació lingüística ha esdevingut també un clixé, una figura literària més, de la retòrica política. La realitat és que l'atac que fa Orwell contra els intel·lectuals, censurats per l'ús que fan del llenguatge, confirma també la seva pròpia pertinença a aquest grup i, en general, confirma també el polèmic estereotip sobre qui són els intel-lectuals. Des de la seva competència cultural i la seva independència desinteressada, Orwell acusa tot un grup, el dels intel-lectuals, tot presentant-se com aliè als seus interessos, malgrat que la seva prosa només es pot llegir com a una manifestació literària de la intel·lectualitat. Xammar i d'altres, en canvi, ocupen una posició en el sistema literari i cultural menys polèmica, però més ambigua. Això no fa d'ells pitjors escriptors o pensadors.

ÀLEX MATAS PONS

Universitat de Barcelona

\section{NOTES}

1 Malgrat que no val la pena fer cap valoració moral de la persona, potser sí cal explicar que un home escèptic com Eugeni Xammar no podia considerar-se de cap manera aliè a la vanitat, però la seva intel-ligència pragmàtica el va fer més procliu a d'altres interessos particulars. Així rememora amb ironia un episodi de la seva biografia: "Carles Esplà em va preguntar un dia, tot passant, si m’agradaria ésser gobernador civil i jo li vaig contestar que sí, que molt, perquè jo sóc un home - ho confesso sincerament - al qual, 
com deia d'ell mateix Francesc Pujols, li hauria agradat molt «figurar». Però a la vida totes les coses, àdhuc la vanitat, tenen un preu i a Espanya els governadors civils treballaven per molts pocs diners, la quarta part si fa no fa del que jo guanyava a Berlín fent de periodista i traductor" (Xammar, Seixanta 350).

2 L'historiador Peter Fritzsche resumeix de la següent manera l'escena periodística que Xammar valora: “De hecho, Berlín tenía la mayor densidad de periódicos de Europa. En la década de 1920, las tres grandes editoriales de la ciudad publicaban ediciones especiales al mediodía, a la tarde o a la noche (BZ am Mittang, de Ullstein; 8-Uhr Abendblatt, de Mosse; Nacht-Ausgabe, de Scherl) junto a sus diarios insignia: Berliner Morgenpost, Berliner Tageblatt y Berliner Lokal-Anzeiger. Los diarios que se dirigían a los habitantes de los suburbios (Die Grüne Post), a los intelectuales de la zona occidental (Vossiche Zeitung) o a los hombres de negocios (Berliner Börsen-Courier) también proliferaban. Cada semana salían a la calle 93 periódicos” (31).

3 Xammar arriba a Berlín després del judici contra els criminals que van matar Rathenau. Poden, però, llegir-se les cròniques de Joseph Roth, enviat especial del periòdic Neue Berliner Zeitung durant el mes d'octubre de 1922. La lectura del procés Rathenau descrit per Roth (23-40) i del procés Harden descrit per Xammar evidencien el trist espectacle dels tribunals alemanys d'aleshores i la lleugeresa de les penes imposades als agents de les forces reaccionàries. Sobre el sistema judicial dels primers anys de la República, Peter Gay diu: "entre 1918 y 1922, los asesinatos imputables a elementos de izquierdas fueron veintidós; de ellos, diecisiete fueron severamente castigados, diez de ellos con la pena capital. Por el contrario, los extremistas de derechas fueron juzgados con benevolencia: de los 354 asesinatos cometidos, sólo uno fue severamente castigado y no con la pena de muerte" (40).

4 Vegeu en particular el capítol titulat "Creo en él” del llibre de Victor Klemperer LTI. La lengua del Tercer Reich. Apuntes de un filólogo.

5 La presentación que es fa aquí de Siegfried Kracauer es fa sobretot a partir de dos dels seus textos més coneguts, "Els empleats" i “La massa com ornament". Les biografies intel·lectuals de Siegfried Kracauer escrites per Enzo Traverso i Olivier Agard són especialment recomanables si es vol entendre quin paper juguen en particular aquestes dues obres en el conjunt del pensament del sociòleg alemany.

\section{REFERÈNCIES}

Agard, Olivier. Kracauer. Le chiffonnier mélancolique. Paris: CNRS, 2010.

Bourdieu, Pierre. "Campo del poder, campo intelectual y habitus de clase". Intelectuales, politica y poder. Buenos Aires: Eudeba. 2003. 23-42.

Fritzsche, Peter. Berlín 1900. Prensa, lectores y vida moderna. Buenos Aires: Siglo Veintiuno, 2008.

Gay, Peter, La cultura de Weimar. Barcelona: Paidós, 2011.

Klemperer, Victor. LTI. La lengua del Tercer Reich: Apuntes de un filólogo. Barcelona: Minúscula, 2004.

—. Assaigs. València: Publicacions de la Universitat de València, 2008.

Kracauer, Siegfried. Los empleados. Barcelona: Gedisa, 2007. 
-. "El ornamento de la masa". La fotografía y otros ensayos. Barcelona: Gedisa, 2008. 51-65.

Orwell, George. "Politics and the English Language". The Collected Essays, Journalism and Letters of George Orwell. Vol IV. Londres: Secker \& Warburg, 1968. 127-140.

Roth, Joseph. El juicio de la historia. Escritos 1920-1939. Madrid: S. XXI, 2004.

Traverso, Enzo. Siegfried Kracauer. Itinerario de un intelectual nómada. Valencia: Edicions Alfons el Magnànim, 1997.

Trilling, Lionel. "George Orwell y la política de la verdad”. El yo antagónico. Nueve ensayos críticos. Madrid: Taurus, 1974. 153-172.

Xammar, Eugeni. L'ou de la serp. Barcelona: Quaderns Crema, 1998.

-. Crónicas desde Berlín (1930-1936). Barcelona: Acantilado, 2005.

- Seixanta anys d'anar pel món. Barcelona: Pòrtic, 1975. 